\title{
煎茶用品種“みやまかおり’の育成
}

\author{
宮崎県総合農業試験場茶業支場* \\ 長友博文・水田隆史・佐藤邦彦 \\ 宮崎県西臼杵農業改良普及センター** \\ 吉留 浩 \\ 元宮崎県総合農業試験場茶業支場
}

古野鶴吉・上野貞一・平川今夫・間曽龍一・安部二生

(平成15年11月26日受理)

\section{A New Cultivar 'Miyamakaori' for Green Tea}

\author{
Hirofumi Nagatomo, Takashi Mizuta, Kunihiko Sato \\ Tsuruyoshi Furuno, Sadaichi Ueno, Imao Hirakawa, \\ Ryuichi Maso and Tsugio Abe \\ Tea Branch, Miyazaki Prefectural Agricultural Experiment Station \\ Hiroshi Yoshida \\ Nishiusuki Agricultural Extension Center
}

\section{Summary}

A new cultivar 'Miyamakaori' for green tea was bred at the Tea Branch, Miyazaki Prefectural Agricultural Experiment Station and registered as Cha Norin №.52 by the Ministry of Agriculture, Forestry and Fisheries in September, 2003. This cultivar was selected out of seedlings crossed between 'Kyoken283' and 'Saitama No.1' in 1983.

The characteristics of the cultivar are as follows ;

This cultivar is late budding, both the flushing and the plucking times of the 1st crop are 2 days later than in 'Okumidori'. The shape of the plant is intermediate type and the growth is vigorous. The color of immature leaves is light green. The plucked new shoots are bud weight type.

It is middle susceptible to tea anthracnose (Colletotrichum theae-sinensis) and slightly resistant to tea gray blight (Pestalotiopsis longiseta). It is fairly resistant to cold in midwinter and middle resistant to bark split frost injury in earlywinter. The annual green leaf yield is higher than that of 'Yabukita'.

Quality of the processed tea is as good as 'Yabukita'. The aroma is something like boiled chestnuts and the taste is mild.

Key words: 'Miyamakaori', new cultivar, green tea, late budding, hight-yielding ability

$\begin{array}{lll}* & \mathbf{7} 889-1301 & \text { 宮崎県坚湯郡川南町大字川南17070 } \\ * * & \bar{T} 882-1101 & \text { 宮崎県西臼杵郡高千穂町大字三田井字堂山3364-39 }\end{array}$ 


\section{1 緒}

言

現在, 全国の茶栽培面積の約 $77 \%$ を生品種 のやぶきた’が占めている†。宮崎県においては, ‘やぶきた’の比率は約63\%と全国的には比較的少 ない方であるが†，それでも摘採作業が集中する 場合が散見され，経営規模の拡大や製茶施設の 大型化を図る上で問題となっている。このため, 収穫時期の分散を可能にする早・中・晚生品種 の育成が求められている。

宮崎県総合農業試験場茶業支場(農林水産省 茶育種指定試験地)では, 平坦地から中山間地域 まで幅広く栽培できるよう, 晩生の゙おくみどり’ より遅く収穫でき, 良質, 多収の煎茶用品種茶 農林52号“みやかおり’を育成したので,その来 歴, 育成経過並びに試験成績の概要を報告する。 なお, 本品種の育成に際し, 栄養系適応性 検定試験 (以下, 系適試験という), 特性検定試 験及び県単独事業による地域適応性検定試験等 にご協力いただいた関係場所を以下に記し, 関 係者各位に深甚の謝意を表する。

\section{農林水産省指定系適試験場所}

茨城県農業総合センター山間地帯特産指導所 三重県科学技術振興センター農業研究部茶業 研究室

京都府立茶業研究所

高知県農業技術センタ一茶業試験場

熊本県農業研究センター茶業研究所

農林水産省指定特性検定試験場所

静岡県茶業試験場（もち病抵抗性）

鹿児島県茶業試験場（裂傷型凍害抵抗性）

県単独事業による地域適応性検定試験場所
埼玉県農林総合研笁センター特産支所 (現農林総合研究センター茶業特産研究所) 静岡県茶業試験場

滋賀県農業総合センタ一茶業指導所 奈良県農業技術センター茶業振興センター 香川県農業試験場満濃分場 福岡県農業総合試験場八女分場 佐賀県茶業試験場 長崎県総合農林試験場東彼杵茶業支場 大分県農業技術センター茶業特産部 鹿児島県茶業試験場

\section{2 来歴及ひ育成経過}

‘やまかおり’は, 交配から農林登録まで, 当 支場で育成された‘さきみどり’ 18 年に次いで短 い20年で育成されており，育成には 9 名の関係 者が携わっている。

本品種は, 1983年に当支場において, 晚生で 良質の京研283’を種子親, 晚生で多収の埼玉 1 号'を花粉親として交配を行い, 得られた1,400個 体の中から選抜して育成したものである(図 1)。 1984年 9 月に採種し, 同年 11 月に 1,400 個体 を戋場に播種した。1985年から1987年までの 3 年間個体選拔試験を行い, 葉色及び而病性等の 優れた 8 個体について1987年 6 月に挿し木を 行った。1988年 5 月に定植し，1993年までの 6 年間'Mi88-86’の系統名で栄養系比較試験を実 施し，生育及び品質特性を調查した。

1994年から“宮崎20号”の系統名で茨城, 三重, 京都, 高知, 熊本の各府県で系適試験 (第 8 群) を, 静岡県 (もち病), 鹿児島県 (裂傷型凍害) で特性検定試験及び県単試験を開始した。また, 1995年からは新たに 9 県（宮崎県を含む）の公

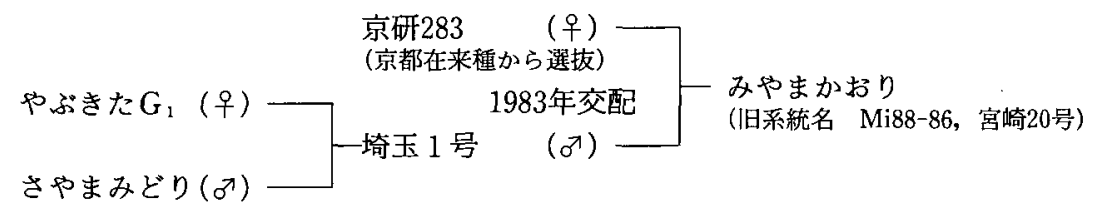

図 1 'みやまかおり’の育成系統図

$\dagger$ 社団法人日本茶業中央会: 平成 15 年度版茶関係資料, p 25 
(茶研報96：1 13，2003）

表】‘みやまかおり’の新品種としての有望度 ${ }^{\mathrm{a}}$

\begin{tabular}{|c|c|c|c|c|c|c|c|c|c|}
\hline 場 & 所 & 有 & 望 & 度 & 場 & 所 & 有 & 望 & 度 \\
\hline 茨 & 城 & & 5 & & 奈 & 良 & & 4 & \\
\hline$\equiv$ & 重 & & 5 & & 香 & $\|$ & & 4 & \\
\hline 京 & 都 & & 3 & & 福 & 岡 & & 4 & \\
\hline 高 & 知 & & 4 & & 佐 & 賀 & & 5 & \\
\hline 熊 & 本 & & 5 & & 長 & 崎 & & 4 & \\
\hline 滋 & 賀 & & 5 & & 大 & 分 & & 2 & \\
\hline
\end{tabular}

$\mathrm{a}$ 有望度は系適試験最終年度の評価

評価：1 (見込みなし)〜 5 (有望)

立場所でも県単試験を開始した。2002年までの 系適試験の結果, 晚生で収量性及び製茶品質が 優れ，普及性が高いと判断されたので，2003年 1月に開催された「茶新品種候補検討委員会」 及び同年 3 月の「平成 14 年度野菜・茶業試験研 究推進会議」での審議を経て，農林水産大臣に 新品種命名登録申請を行った。

その結果, 2003年 9 月 5 日に茶農林 52 号“みや まか扔り’として農林登録された。

最終年度における各県の有望度は表 1 のとお りで, 有望とした県は有望度について評価した
12 府県中 5 県, やや有望とした県は 5 県で高い 評価が得られた。

\section{3 特性の概 要}

3.1 形態的特性

樹姿は中間型で, 樹勢は強, 株張りはやや大 である。枝条の節間長及び太さは‘やぶきた’と同 程度である。着葉角度はやや鋭角である(表 2 )。 新葉の形状は長だ円, 大きさ及び葉厚は中, 葉 色は淡緑である。光沢はやや多,葉質はやや軟で， 葉裏には全面に毛茸が密生している(表 3 )。成

\section{表 2 育成地における一般特性及び生育特性}

\begin{tabular}{|c|c|c|c|c|c|c|c|}
\hline \multirow[b]{2}{*}{ 品種名 } & \multirow[b]{2}{*}{ 樹 } & \multirow[b]{2}{*}{ 樹 勢 } & \multirow[b]{2}{*}{ 株 張り } & \multirow{2}{*}{$\begin{array}{l}\text { 葉層の } \\
\text { 厚 さ }\end{array}$} & \multicolumn{2}{|c|}{ 枝条の形質 ${ }^{a}$} & \multirow[b]{2}{*}{ 着葉角度 } \\
\hline & & & & & $\begin{array}{c}\text { 節間長 } \\
(\mathrm{cm})\end{array}$ & $\begin{array}{c}太 \mathrm{~d} \\
(\mathrm{~mm})\end{array}$ & \\
\hline みやまかおり & 中間 & 強 & や队大 & 中 & 5.06 & 3.31 & やや鋭 \\
\hline やぶきた & やや直立 & やや強 & 中 & 中 & 4.98 & 3.39 & やや鋭 \\
\hline かなやみどり & 開張 & 中 & 大 & やゃ厚 & 4.38 & 3.26 & 中 \\
\hline おくみどり & やや直立 & 中 & 中 & 厚 & - & - & 中 \\
\hline
\end{tabular}

a 枝条の形質は, 一番茶硬化枝条の中央部を測定。2001年調查

\section{表 3 育成地における新葉の形質}

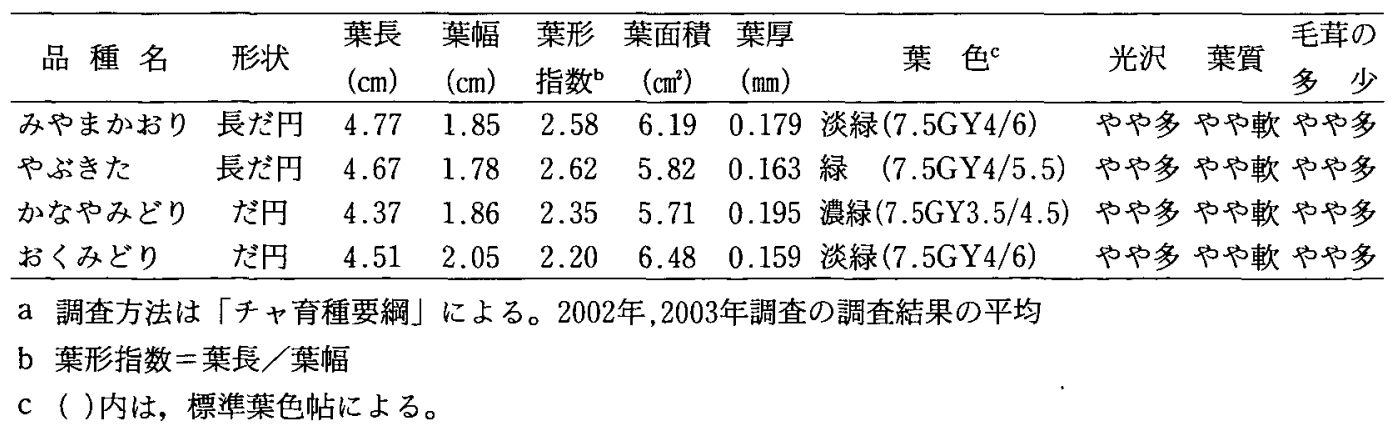


葉の形状は長卵形で，大きさは大，葉厚はやや 薄, 葉色は淡緑である（表 4 ）。

\section{2 萌芽期及び摘採期}

育成地における一番茶の萌芽期は 4 月11日で ‘やぶきた’より9日遅く，摘採期は‘やぶきた’よ り 7 日遅い 5 月 4 日であった。また, 現在普及 している品種の中で最も晩生に属する゙おくみど り’より萌芽期, 摘採期とも 2 日遅く, 品種の組 合せにより摘採期間の拡大か期待できる(表 5 )。 系適試験においては, 萌芽期は全場所平均で ‘やぶきた’に比べ 7 日遅く，摘採期は 6 日遅かつ た。なお，“おくみどり’との比較では, 奈良県で は萌芽期，摘採期ともほぼ同じ，佐賀県ではと もに゙扔くみどり’より 3 日遅かった（表 6 ）。

\section{3 生育及び収量}

系適試験における育苗成續では, 苗の生存率 は平均 $90 \%$, 生育が 5 段階評価で 4.5 と評価さ れ，ややぶさた’同85\%，4.0)より優れている。
定植後の活着率の平均は97\%で, ‘やぶきた’(同 $97 \%$ ）と同程度である。樹勢が強く，定植 5 年 目の株張りもほとんどの場所でやぶきた’より大 きく, 奈良県, 佐賀県では対照品種の゙おくみど り’より生育が良かった（表 7 ）。

育成地の系適試験における10a当たり生葉収量 は, $3 \sim 5$ 年生の平均で, 一番茶が $276 \mathrm{~kg}$ ('や ぶきた’比185\%)，二番茶は $367 \mathrm{~kg}$ (同176\%) と 多収であった。また，摘採面当たり収量におい ても，ややぶぎ比で一番茶では152\%，二番茶 では183\%を示している(表 8)。このことから， 本品種は‘やぶきたりに比べ株張りが大きいことだ けでなく,百芽重及び摘芽数がやぶきだ上回っ ていることも多収の要因になっているものと考 えられた（表 7 , 表 9 )。

表 6 に系適試験における $5 \sim 7$ 年生の生葉収 量を示した。一番茶, 二番茶とも滋賀県, 福岡 県を除く全ての府県でやぶきた’を回っており， 全場所平均は一番茶では‘やぶきた’比で147\%， 二番茶では $170 \%$ となっており,成木園でもある

表 4 青成地における成葉の形質 ${ }^{a}$

\begin{tabular}{|c|c|c|c|c|c|c|c|c|c|c|c|c|}
\hline & 形状 & $\begin{array}{l}\text { 葉長 } \\
(\mathrm{cm})\end{array}$ & $\begin{array}{l}\text { 葉幅 } \\
\text { (cm) }\end{array}$ & $\begin{array}{l}\text { 葉形 } \\
\text { 指数 }\end{array}$ & $\begin{array}{c}\text { 葉面積 } \\
\left(\mathrm{cm}^{2}\right)\end{array}$ & $\begin{array}{l}\text { 葉厚 } \\
(\mathrm{mm})\end{array}$ & 葉 色 ${ }^{c}$ & 光沢 & $\begin{array}{c}\text { 葉面の } \\
\text { しわ }\end{array}$ & $\begin{array}{l}\text { 葉緑 } \\
\text { の波 }\end{array}$ & & \\
\hline & & 9.64 & .09 & 2.36 & 27.8 & 0.237 & & \% & やや多 & やや少 & やや少 & 中 \\
\hline & 長だ & 8.87 & 3.46 & 2.57 & 21.9 & 0.259 & 緑（7. & やや多 & 中 & 中 & 中 & 中 \\
\hline かなやみどり & 長卵 & 8.18 & 3.38 & 2.43 & 19.9 & 0.257 & 灙緑(7.5GY3.5/4) & 多 & やや少 & やや少 & 中 & 中 \\
\hline
\end{tabular}

a 調查方法は「チャ育種要綱」による。2002年,2003年調査の調查結果の平均

b 葉形指数 $=$ 葉長 /葉幅

c（）内㹥，標準葉色帖による。

表 5 育成地における萌芽期及び摘採期

\begin{tabular}{|c|c|c|c|c|c|c|c|c|c|c|c|c|c|c|c|}
\hline & \multirow{2}{*}{ 品種名 } & \multicolumn{6}{|c|}{ 栄養系比較試験（月日） } & \multicolumn{6}{|c|}{ 系適試験（月日） } & \multirow{2}{*}{ 全平均 } & \multirow{2}{*}{$\begin{array}{r}\text { 比較 }^{8} \\
\text { (日) }\end{array}$} \\
\hline & & 1989年 & 1990年 & 1991年 & 1992年 & 1993年 & 平均 & 比榦(日) & 2000 年 & 2001年 & 2002年 & 平均 & 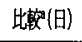 & & \\
\hline \multirow{4}{*}{ 萌芽期 } & みやまかおり & 4.17 & 4. 8 & 4.10 & 4. 7 & 4.18 & 4.12 & +9 & 4.13 & 4. 9 & 4. 7 & 4.10 & +8 & 4.11 & +9 \\
\hline & やぶきた & 4. 7 & 3.30 & 3.31 & 4. 1 & 4.10 & 4. 3 & \pm 0 & 4. 8 & 4. 1 & 3.29 & 4. 2 & \pm 0 & 4. 2 & \pm 0 \\
\hline & かなやみどり & 4. 9 & 4. 3 & 4. 4 & 4. 4 & 4.13 & 4. 6 & +3 & 4.10 & 4.13 & 4. 2 & 4. 5 & +3 & 4. 5 & +3 \\
\hline & おくみどり & 4.12 & 4.8 & 4.10 & 4. 8 & 4.16 & 4.10 & +7 & - & - & - & - & - & - & - \\
\hline \multirow{4}{*}{ 摘採期 } & みやまかおり & - & 5. 7 & 5.1 & 5. 1 & 5.13 & 5. 5 & +7 & 5. 6 & 5. 5 & 4.29 & 5. 3 & +7 & 5. 4 & +7 \\
\hline & やぶきた & - & 4.28 & 4.21 & 4.25 & 5. 9 & 4.28 & \pm 0 & 5. 1 & 4.26 & 4.22 & 4.26 & \pm 0 & 4.27 & \pm 0 \\
\hline & かなやみどり & - & 5. 2 & 4.24 & 4.26 & 5. 8 & 4.30 & +2 & 5. 2 & 5. 2 & 4.26 & 4.30 & +4 & 4.30 & +3 \\
\hline & おくみどり & - & 5. 4 & 4.26 & 5.1 & 5.11 & 5.3 & +5 & - & - & - & - & - & - & - \\
\hline
\end{tabular}

a ‘やぶきた’より早いものを一n日, 遅いものを十n日で表示 
(茶研報96：1 13, 2003)

表 6 系適試験における萌芽期, 摘採期及び収量

\begin{tabular}{|c|c|c|c|c|c|c|c|c|c|}
\hline \multirow[b]{2}{*}{ 場 所 } & \multirow[b]{2}{*}{ 品 種 名 } & \multicolumn{2}{|c|}{ 萌芽期 ${ }^{a}$} & \multicolumn{2}{|c|}{ 摘採期 ${ }^{\mathrm{a}}$} & \multicolumn{4}{|c|}{ 生葉収量 ${ }^{b}$} \\
\hline & & 月日 & $\begin{array}{l}\text { 比較 }^{b} \\
\text { (日) }\end{array}$ & 月日 & $\begin{array}{l}\text { 比較 }^{b} \\
\text { (日) }\end{array}$ & $\begin{array}{c}\text { 一番菜 } \\
(\mathrm{kg} / 10 \mathrm{a})\end{array}$ & 指数 ${ }^{d}$ & $\begin{array}{c}\text { 二番䒩 } \\
(\mathrm{kg} / 10 \mathrm{a})\end{array}$ & 指数 ${ }^{\mathrm{d}}$ \\
\hline \multirow{3}{*}{ 茨 } & みやまかおり & $4.20^{\mathrm{e}}$ & +5 & $5.23^{\mathrm{e}}$ & +4 & $218^{\mathrm{j}}$ & 123 & $294^{\mathrm{j}}$ & 254 \\
\hline & やぶきた & 4.15 & \pm 0 & 5.19 & \pm 0 & 177 & 100 & 116 & 100 \\
\hline & かなやみどり & 4.15 & +1 & 5.20 & +2 & 197 & 111 & 162 & 140 \\
\hline \multirow{3}{*}{ 三 } & みやまかおり & $4.13^{f}$ & +5 & 5. $6^{\mathrm{f}}$ & +7 & $347^{j}$ & 199 & $470^{\mathrm{j}}$ & 129 \\
\hline & やぶきた & 4. 8 & \pm 0 & 4.28 & \pm 0 & 175 & 100 & 364 & 100 \\
\hline & かなやみどり & 4.11 & +3 & 5. 5 & +7 & 215 & 123 & 245 & 67 \\
\hline \multirow{3}{*}{ 京 } & みやまかおり & $4.13^{\mathrm{e}}$ & +8 & $5.8^{e}$ & +5 & $243^{\mathrm{j}}$ & 156 & $188^{n}$ & 145 \\
\hline & やぶきた & 4. 5 & \pm 0 & 5. 3 & \pm 0 & 156 & 100 & 130 & 100 \\
\hline & かなやみどり & 4. 9 & +4 & 5. 6 & +3 & 88 & 56 & 43 & 33 \\
\hline \multirow{3}{*}{ 高 } & みやまかおり & 4. $9^{\mathbf{e}}$ & +8 & $5.6^{\mathrm{e}}$ & +4 & $367^{j}$ & 137 & $338^{j}$ & 166 \\
\hline & やぶきた & 4. 1 & \pm 0 & 5. 1 & \pm 0 & 267 & 100 & 204 & 100 \\
\hline & かなやみどり & 4. 5 & +4 & 5. 5 & +4 & 193 & 72 & 132 & 64 \\
\hline \multirow{3}{*}{ 熊 } & みやまかおり & $4.4^{\mathrm{e}}$ & +6 & $4.30^{\circ}$ & +5 & $357^{\mathbf{j}}$ & 174 & $184^{\circ}$ & 227 \\
\hline & やふきさ & 3.30 & \pm 0 & 4.25 & \pm 0 & 205 & 100 & 81 & 100 \\
\hline & かなやみどり & 4. 2 & +3 & 4.27 & +2 & 208 & 101 & 53 & 65 \\
\hline \multirow{2}{*}{ 埼 } & みやまかおり & $4.21^{\mathrm{g}}$ & +6 & $5.20^{\mathrm{g}}$ & +2 & - & - & - & - \\
\hline & やぶきた & 4.16 & \pm 0 & 5.18 & \pm 0 & - & - & - & - \\
\hline \multirow{3}{*}{ 静 } & みやまか抢り & $4.13^{\mathrm{e}}$ & +6 & $5.9^{\mathrm{e}}$ & +6 & $399^{j}$ & 146 & $526^{j}$ & 210 \\
\hline & やぶきた & 4. 6 & \pm 0 & 5. 3 & \pm 0 & 274 & 100 & 250 & 100 \\
\hline & かなやみどり & 4.12 & +6 & 5. 8 & +5 & 221 & 81 & 145 & 58 \\
\hline & みやまかおり & $4.2^{\mathrm{h}}$ & \pm 0 & 5. $9^{h}$ & +7 & $187^{\mathrm{k}}$ & 91 & $90^{\mathbf{k}}$ & 39 \\
\hline 濼 & やぶきた & 4. 2 & \pm 0 & 5. 2 & \pm 0 & 206 & 100 & 229 & 100 \\
\hline & みやまかおり & $4.21^{f}$ & +7 & $5.16^{1}$ & +2 & $178^{1}$ & 176 & $351^{\circ}$ & 297 \\
\hline & やぶさた & 4.14 & \pm 0 & 5.14 & \pm 0 & 101 & 100 & 118 & 100 \\
\hline 良 & かなやみどり & 4.15 & +1 & 5.14 & +1 & 80 & 79 & 216 & 183 \\
\hline & おくみどり & 4.20 & +7 & 5.16 & +2 & 111 & 110 & 202 & 171 \\
\hline & みやまかおり & $4.18^{\mathrm{f}}$ & +9 & $5.10^{\mathrm{f}}$ & +6 & $404^{\mathrm{m}}$ & 192 & $844^{\mathrm{m}}$ & 266 \\
\hline 川 & やぶきた & 4. 9 & \pm 0 & 5. 4 & \pm 0 & 210 & 100 & 317 & 100 \\
\hline & かなやみどり & 4.12 & +3 & 5. 7 & +3 & 117 & 55 & 196 & 62 \\
\hline & みやまかおり & $4.11^{\mathrm{f}}$ & +10 & $5.6^{f}$ & +6 & $235^{\mathrm{m}}$ & 84 & $86^{\mathrm{n}}$ & 41 \\
\hline 偪 & やぶきた & 4. 1 & \pm 0 & 5.1 & \pm 0 & 278 & 100 & 210 & 100 \\
\hline & みやまかおり & $4.15^{\mathrm{f}}$ & +9 & $5.10^{f}$ & +8 & $420^{\mathrm{m}}$ & 158 & $464^{\mathrm{m}}$ & 244 \\
\hline 賀 & やぶきた & 4. 6 & \pm 0 & 5. 2 & \pm 0 & 266 & 100 & 190 & 100 \\
\hline & おくみどり & 4.12 & +6 & 5.7 & +5 & 335 & 126 & 355 & 187 \\
\hline & みやまかおり & $4.17^{f}$ & +11 & $5.11^{f}$ & +6 & $416^{\mathrm{m}}$ & 143 & $200^{\mathrm{m}}$ & 166 \\
\hline 崎 & やぶきた & 4. 6 & \pm 0 & 5. 5 & \pm 0 & 290 & 100 & 121 & 100 \\
\hline & みやまかおり & $4.13^{\mathrm{f}}$ & +6 & $5.15^{f}$ & +5 & $324^{\mathrm{m}}$ & 115 & $189^{k}$ & 177 \\
\hline 分 & やぶきた & 4. 7 & \pm 0 & 5. 9 & \pm 0 & 283 & 100 & 107 & 100 \\
\hline & かなやみどり & 4. 8 & +1 & 5.11 & +1 & 210 & 75 & 61 & 57 \\
\hline & みやまかおり & $4.10^{\mathrm{e}}$ & +8 & $5.3^{\mathrm{e}}$ & +7 & $341^{\mathrm{n}}$ & 156 & $328^{n}$ & 139 \\
\hline 崎 & やぶきた & 4. 2 & \pm 0 & 4.26 & \pm 0 & 219 & 100 & 236 & 100 \\
\hline & かなやみどり & 4. 5 & +3 & 4.30 & +4 & 293 & 134 & 270 & 114 \\
\hline & みやまかおり & 4. $9^{\mathrm{e}}$ & +6 & $5.3^{f}$ & +6 & $608^{j}$ & 188 & $577^{j}$ & 166 \\
\hline 鹿児島 & やぶきた & 4. 2 & \pm 0 & $4.27^{\circ}$ & \pm 0 & 323 & 100 & 348 & 100 \\
\hline & かなやみどり & 4. 7 & +5 & 5. 1 & +4 & 293 & 91 & 342 & 98 \\
\hline & みやまかおり & 4.13 & +7 & 5.9 & +6 & 336 & 147 & 342 & 170 \\
\hline 均 & やぶきた & 4. 6 & \pm 0 & 5. 4 & \pm 0 & 229 & 100 & 201 & 100 \\
\hline & かなやみどり & 4. 9 & +3 & 5. 7 & +5 & 192 & 84 & 170 & 84 \\
\hline
\end{tabular}

$\mathrm{a}$ eは1999〜2002年の平均，fは2000～2002年の平均，gは1999〜2000年の平均，hは2002年，iは2000，2002年 の平均

$\mathrm{b} \mathrm{j}$ は $5 \sim 7$ 年生の平均, $\mathrm{k}$ は 6 年生, 1 は 5,7 年生の平均, $\mathrm{m}$ は $5 \sim 6$ 年生の平均, $\mathrm{n}$ は 5 年生, 。は 7 年生

c ‘やぶきた’より早いものをーn日, 遅いものを+n日で表示。なお, 四捨五入の関係で月日の差と一致しな い場合がある。

d ‘やぶきた’を100としたときの值 
表 7 系適試験における育苗成績及び生育

\begin{tabular}{|c|c|c|c|c|c|c|c|c|c|c|}
\hline \multirow[b]{2}{*}{ 場 所 } & \multirow[b]{2}{*}{ 品 種 名 } & \multicolumn{2}{|c|}{ 育苗成續 } & \multirow{2}{*}{$\begin{array}{c}1 \text { 年生 } \\
\text { 活着率 } \\
(\%)\end{array}$} & \multicolumn{4}{|c|}{ 定植 2 年目 } & \multicolumn{2}{|c|}{ 定植 5 年目 } \\
\hline & & $\begin{array}{c}\text { 生存率 } \\
(\%)\end{array}$ & $\begin{array}{c}\text { 生育の } \\
\text { 良否 }\end{array}$ & & $\begin{array}{l}\begin{array}{l}\text { 樹高 } \\
(\mathrm{cm})\end{array} \\
\end{array}$ & $\begin{array}{c}\text { 株張り } \\
(\mathrm{cm})\end{array}$ & $\begin{array}{c}\text { 株張り } \\
\text { 指数 }\end{array}$ & $\begin{array}{l}\text { 生育の } \\
\text { 良否 }\end{array}$ & $\begin{array}{c}\text { 株張り } \\
(\mathrm{cm})\end{array}$ & $\begin{array}{l}\text { 生育の } \\
\text { 良否 }\end{array}$ \\
\hline \multirow{4}{*}{ 茨 倜 } & みやまかおり & 97 & 5 & 100 & 62 & 50 & 0.81 & 4 & 120 & - \\
\hline & やぶきた & 95 & 5 & 100 & 66 & 51 & 0.77 & 4 & 100 & - \\
\hline & かなやみどり & 97 & 5 & 100 & 65 & 58 & 0.89 & 4 & 103 & - \\
\hline & みやまかおり & - & - & 88 & 68 & 61 & 0.90 & 3 & 114 & 5 \\
\hline \multirow[t]{2}{*}{ 三 重 } & やぶきた & - & - & 98 & 78 & 61 & 0.78 & 4 & 100 & 4 \\
\hline & かなやみどり & - & - & 40 & 44 & 37 & 0.84 & 1 & 83 & 3 \\
\hline \multirow{3}{*}{ 京 都 } & みやまかおり & 80 & - & 98 & 58 & 54 & 0.93 & 4 & - & - \\
\hline & やぶきた & 100 & - & 100 & 62 & 48 & 0.77 & 3 & - & - \\
\hline & かなやみどり & 32 & - & 91 & 49 & 51 & 1.04 & 2 & - & - \\
\hline \multirow{3}{*}{ 高 知 } & みやまかおり & 85 & 4 & 100 & 105 & 56 & 0.53 & 3 & 118 & - \\
\hline & やぶきた & 74 & 4 & 100 & 130 & 51 & 0.39 & 4 & 104 & - \\
\hline & かなやみどり & 78 & 3 & 100 & 125 & 40 & 0.32 & 4 & 102 & - \\
\hline \multirow{3}{*}{ 熊 本 } & みやまかおり & - & - & 100 & 38 & 34 & 0.89 & 5 & 100 & 5 \\
\hline & やぶきた & - & - & 96 & 37 & 29 & 0.78 & 4 & 87 & 4 \\
\hline & かなやみどり & - & - & 96 & 37 & 35 & 0.95 & 4 & 91 & 4 \\
\hline \multirow{3}{*}{ 埼 玉 } & みやまかおり & 94 & 3.8 & 98 & 49 & 41 & 0.83 & 4 & - & - \\
\hline & やぶきた & 94 & 4.5 & 93 & 65 & 52 & 0.80 & 4 & - & - \\
\hline & かなやみどり & 90 & 4.3 & - & - & - & - & - & - & - \\
\hline \multirow{3}{*}{ 静 岡 } & みやまかおり & - & - & 100 & 60 & 57 & 0.95 & 4 & 122 & 5 \\
\hline & やぶきた & - & - & 96 & 65 & 49 & 0.75 & 3 & 106 & 2 \\
\hline & かなやみどり & - & - & 100 & 63 & 60 & 0.95 & 4 & 109 & 1 \\
\hline \multirow{3}{*}{ 滋 賀 } & みやまかおり & 99 & 4 & 95 & 61 & 53 & 0.88 & 4 & 109 & 5 \\
\hline & やぶきた & 84 & 3 & 85 & 60 & 47 & 0.78 & 3 & 81 & 3 \\
\hline & かなやみどり & 89 & 3 & 98 & 56 & 49 & 0.88 & 3 & 78 & 3 \\
\hline \multirow{4}{*}{ 奈 良 } & みやまかおり & 93 & 4 & - & - & - & - & - & 118 & 5 \\
\hline & やぶきた & 98 & 4 & - & - & - & - & - & 77 & 2 \\
\hline & かなやみどり & 97 & 3 & - & - & - & - & - & 86 & 1 \\
\hline & おくみどり & - & - & - & - & - & - & - & 93 & 4 \\
\hline \multirow{3}{*}{ 香 川 } & みやまかおり & 68 & 5 & 100 & 126 & $\overline{103}$ & 0.82 & 4 & 153 & - \\
\hline & やぶきた & 52 & 3 & 97 & 154 & 80 & 0.52 & 4 & 105 & - \\
\hline & かなやみどり & 34 & 4 & 100 & 148 & 98 & 0.66 & 4 & 104 & - \\
\hline \multirow{3}{*}{ 福 岡 } & みややかおり & 100 & 5 & 100 & 67 & 37 & 0.55 & 4 & 109 & - \\
\hline & やぶきた & 92 & 4.5 & 100 & 99 & 46 & 0.46 & 5 & 121 & - \\
\hline & かなやみどり & 87 & 3.5 & 100 & 70 & 50 & 0.71 & 3 & 64 & - \\
\hline & みやまかおり & - & - & 88 & 56 & 60 & 1.07 & 4 & 196 & - \\
\hline 佐 賀 & やぶきた & - & - & 98 & 58 & 58 & 1.00 & 3 & 168 & - \\
\hline & おくみどり & - & - & 98 & 60 & 48 & 0.80 & 3 & 181 & - \\
\hline 長 㥓 & みやまかおり & - & - & 91 & - & - & - & - & 156 & - \\
\hline & やぶきた & - & - & 100 & - & - & - & - & 126 & - \\
\hline & みやまかおり & 90 & 5 & 100 & 87 & 69 & 0.79 & 4 & 130 & - \\
\hline 大 分 & やぶきた & 77 & 4 & 97 & 106 & 58 & 0.55 & 4 & 117 & - \\
\hline & かなやみどり & 85 & 4 & 100 & 123 & 74 & 0.60 & 5 & 132 & - \\
\hline & みやまかおり & - & - & - & 63 & 74 & 1.17 & 5 & 143 & - \\
\hline 崎 & やぶきた & - & - & - & 64 & 73 & 1.14 & 5 & 131 & - \\
\hline & かなやみどり & - & - & - & 63 & 95 & 1.51 & 4 & 152 & - \\
\hline & みやまかおり & - & - & 100 & 95 & 67 & 0.71 & 5 & - & $=$ \\
\hline 鹿児島 & やぷきた & - & - & 100 & 115 & 65 & 0.57 & 5 & - & - \\
\hline & かなやみどり & - & - & 100 & 105 & 57 & 0.54 & 4 & - & - \\
\hline & みやまかおり & 90 & 4.5 & 97 & 71 & 58 & 0.82 & 4.0 & 130 & 5.0 \\
\hline 平 均 & やぶきた & 85 & 4.0 & 97 & 83 & 55 & 0.66 & 3.9 & 109 & 3.0 \\
\hline & かなやみどり & 76 & 3.7 & 93 & 79 & 59 & 0.75 & 3.5 & 100 & 2.4 \\
\hline
\end{tabular}

$\mathrm{a}$ 生育の良否: 1 (劣) 5 (良)

$\mathrm{b}$ 株張り指数二株張り /樹高 
(茶研報96：1～13，2003）

程度の多収が期待できるものと考えられた。

\section{4 而寒性}

育成地に扔ける厳寒期の成葉の赤枯れ発生 程度は‘やぶきた’と同程度で, 抵抗性はやや強と 考えられる(表10)。寒さの厳しい茨城県や埼玉 県でも‘やぶきた’と同程度と評価されており(表 11), 暖地, 温暖地及び関東地域であれば栽培に 支障はないと考えられる。

秋芽の伸育停止期は，‘やぶきた’と同程度で, ‘おくみどり’よりやや早い（表12）。

初冬及び早春に発生する裂傷型凍害について

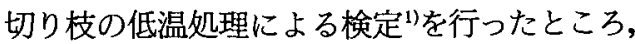

‘やぶきた’と同程度の中と判断した (表13)。特 性検定試験として鹿児島県で行った裂傷型凍害 抵抗性においても‘やぶきた’と同程度の中と評価 された（表14）。

\section{5 耐病虫性}

育成地における炭疽病抵抗性は中で, ‘やぶき た，おくみどり'より強かったが，多発が予想さ れる場合には防除が必要である（表15）。

輪斑病 (Pestalotiopsis longiseta) については, 分生胞子の付傷接種による人為検定を古野2)方 法で行った。なお，評価基準については古野ら がその後改訂した基準たによった。

\section{表 8 青成地の系適試験における生葉収量}

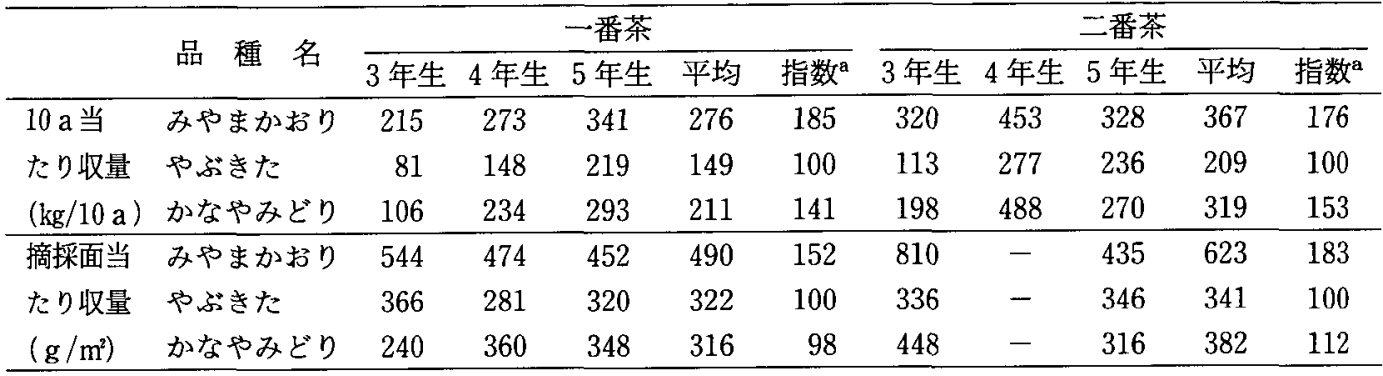

a ‘やぶきた’を100としたときの值

\section{表 9 育成地における一番茶摘採期の摘芽の形質 ${ }^{\mathrm{a}}$}

\begin{tabular}{|c|c|c|c|c|c|c|c|}
\hline 品 & 種 & $\begin{array}{l}\text { 摘芽数 } \\
\left(\text { 本 } / \mathrm{m}^{2}\right)\end{array}$ & $\begin{array}{c}\text { 摘芽長 } \\
(\mathrm{cm})\end{array}$ & $\begin{array}{c}\text { 茎の太さ } \\
\text { (mm) }\end{array}$ & $\begin{array}{c}\text { 開葉数 } \\
\text { (枚) }\end{array}$ & $\begin{array}{c}\text { 百芽重 } \\
(\mathrm{g})\end{array}$ & $\begin{array}{c}\text { 出開き度 } \\
(\%)\end{array}$ \\
\hline \multicolumn{2}{|c|}{ みやまかおり } & 1,299 & 9.0 & 2.1 & 3.6 & 66.9 & 23.5 \\
\hline \multicolumn{2}{|c|}{ やぶきた } & 898 & 7.0 & 1.6 & 3.5 & 51.9 & 31.2 \\
\hline \multicolumn{2}{|c|}{ かなやみどり } & 1,222 & 7.6 & 1.7 & 3.5 & 48.9 & 26.2 \\
\hline
\end{tabular}

a 茎の太さは 2002 年調査, 他の項目は2000 2002年 ( $3 \sim 5$ 年生)の平均值

表10 䏍成地における赤枯れ抵抗性 ${ }^{\mathrm{a}}$

\begin{tabular}{|c|c|c|c|c|c|c|c|c|c|c|c|c|c|}
\hline \multirow{2}{*}{ 品 } & \multirow{2}{*}{ 種 } & \multicolumn{6}{|c|}{ 栄養系比較試験 } & \multicolumn{4}{|c|}{ 系 適 試 験 } & \multirow{2}{*}{ 全平均 } & \multirow{2}{*}{ 評価 } \\
\hline & & 1989年 & 1990年 & 1991年 & 1992年 & 1993年 & 平均 & 2000年 & 2001年 & 2002年 & 平均 & & \\
\hline \multicolumn{2}{|c|}{ みやまかおり } & 1.8 & 1.5 & 3.0 & 1.5 & 2.0 & 2.0 & 1.3 & 1.7 & 1.3 & 1.4 & 1.8 & やや弓 \\
\hline \multicolumn{2}{|c|}{ やぶきた } & 2.3 & 2.0 & 2.0 & 1.5 & 1.5 & 1.9 & 1.7 & 2.0 & 1.5 & 1.7 & 1.8 & や強 \\
\hline \multicolumn{2}{|c|}{ かなやみどり } & 1.8 & 1.5 & 2.0 & 1.0 & 1.0 & 1.5 & 1.7 & 1.5 & 1.2 & 1.5 & 1.5 & や強 \\
\hline \multicolumn{2}{|c|}{ おくみどり } & 2.3 & 2.0 & 2.0 & 1.5 & 1.5 & 1.9 & - & - & - & - & 1.9 & やや強 \\
\hline \multicolumn{2}{|c|}{ ゆたかみどり } & 3.9 & 3.0 & 3.5 & 2.5 & 3.5 & 3.3 & 3.0 & 2.7 & 2.8 & 2.8 & 3.1 & やや弱 \\
\hline
\end{tabular}

a 戋場における自然発生程度: 1 (無) 〜 5 (多)

† 2 宮崎県総合農業試験場茶業支場：チャ遺伝資源収集・保存並びに特性調榃成績書,p10（2001） 
表11 系適試験地における耐寒性 ${ }^{\mathrm{a}}$

\begin{tabular}{|c|c|c|c|c|}
\hline 場 & 所 & 品 種 名 & 赤枯れ & 青 枯 れ \\
\hline \multirow{3}{*}{ 茨 } & \multirow{3}{*}{ 城 } & みやまかおり & 1.4 & 1.5 \\
\hline & & やぶきた & 1.2 & 1.0 \\
\hline & & かなやみどり & 1.2 & 1.0 \\
\hline \multirow{2}{*}{ 埼 } & \multirow{2}{*}{$玉^{c}$} & みやまかおり & 3.3 & 2.0 \\
\hline & & やアぶきた & 3.3 & 1.7 \\
\hline
\end{tabular}
a 围場における自然発生程度: 1 (無) 〜 5 (多)
b 赤枯れは 5 力年, 青枯れは 2 力年の平均値
$\mathrm{c}$ 赤枯れ, 青枯れともに 3 力年の平均值

表12 青成地における秋芽の伸青停止の早晩 ${ }^{\mathrm{a}}$

\begin{tabular}{|c|c|c|c|c|c|}
\hline 品 種 名 & 1989年 & 1990年 & 1991年 & 1992年 & 平 \\
\hline みやまかおり & 2.5 & 3.5 & 3.0 & 3.0 & 3.0 \\
\hline やぶきた & 3.0 & 2.5 & 3.5 & 3.0 & 3.0 \\
\hline かなやみどり & 2.0 & 2.5 & 3.0 & 3.0 & 2.6 \\
\hline おくみどり & 3.5 & 4.0 & 4.0 & 3.0 & 3.6 \\
\hline
\end{tabular}

a 秋芽の伸育停止：1 (早) 5 (晚)

表13 育成地における裂傷型凍害抵抗性 ${ }^{\mathrm{a}}$

\begin{tabular}{|c|c|c|c|c|c|c|}
\hline \multirow{2}{*}{ 品 } & \multirow{2}{*}{ 種 } & \multirow{2}{*}{$\begin{array}{c}\text { 1989年 } \\
\text { 11月中旬 }\end{array}$} & \multirow{2}{*}{$\begin{array}{c}\text { 1990年 } \\
\text { 11月下旬 } \\
\text { 12月上旬 }\end{array}$} & \multicolumn{2}{|c|}{ 1999年 } & \multirow{2}{*}{ 評 価 } \\
\hline & & & & 11月上旬 & 12 月上旬 & \\
\hline \multicolumn{2}{|c|}{ みやまかおり } & 4.5 & 2.9 & 3.6 & 1.3 & 中 \\
\hline \multicolumn{2}{|c|}{ やぶきた } & 4.4 & 1.5 & 4.4 & 1.2 & 中 \\
\hline \multicolumn{2}{|c|}{ かなやみどり } & 2.4 & 2.5 & 2.2 & 1.2 & やや強 \\
\hline \multicolumn{2}{|c|}{ おくみどり } & 4.1 & 3.3 & - & - & 中 \\
\hline \multicolumn{2}{|c|}{ ゆたかみどり } & 5.0 & 4.8 & 5.0 & 2.9 & 弱 \\
\hline
\end{tabular}

$\mathrm{a}$ 切り枝の低温処理による検定 $\left(11\right.$ 月 $-4 \sim-7^{\circ} \mathrm{C} 、 12$ 月 $-8 \sim-9^{\circ} \mathrm{C} 、$ 約 16 時間処理） 数值：1 (強) 5 (弱)

\section{表14 裂傷型凍害抵抗性（鹿児島県茶業試験場）}

\begin{tabular}{|c|c|c|c|c|c|c|c|c|c|c|c|}
\hline \multirow{3}{*}{ 品 } & \multicolumn{10}{|c|}{ 人為低温処理による裂傷型凍害発生率 (\%) } & \multirow{3}{*}{$\begin{array}{l}\text { 総合 } \\
\text { 判定 }\end{array}$} \\
\hline & \multirow{2}{*}{$\begin{array}{l}\text { 1994年 } \\
\text { 11月中旬 }\end{array}$} & \multirow{2}{*}{$\begin{array}{l}\text { 1995年 } \\
\text { 11月中旬 }\end{array}$} & \multicolumn{2}{|c|}{ 1996年 } & \multicolumn{2}{|c|}{ 1997年 } & \multicolumn{2}{|c|}{ 1998年 } & \multicolumn{2}{|c|}{ 平均 } & \\
\hline & & & 11月上旬 & 11月下旬 & 11 月上旬 & 11月下旬 & 11月上旬 & 11月下旬 & 11月上旬 & 11月中下旬 & \\
\hline みやまかおり & 30 & 0 & 100 & 60 & 0 & 0 & 30 & 15 & 43.3 & 21.0 & 中 \\
\hline やぶきた & 50 & 10 & 100 & 50 & 0 & 0 & 15 & 0 & 38.3 & 22.0 & 中 \\
\hline ゆたかみどり & 80 & 30 & 100 & 60 & 10 & 10 & 40 & 40 & 50.0 & 44.0 & 弱 \\
\hline さやまかおり & 10 & 0 & 100 & 0 & 0 & 0 & 5 & 0 & 35.0 & 2.0 & 強 \\
\hline かなやみどり & 40 & 20 & 100 & 0 & 0 & 0 & 10 & 0 & 36.7 & 12.0 & 強 \\
\hline
\end{tabular}

$\mathrm{a}$ 標準品種の発生率加ら下記のとおり基準分け

11 月上旬平均 : $37 \%$ 以下 $=$ 強、 $37.1 \sim 44.9 \%=$ 中、 $45 \%$ 以上 $=$ 弱

11月中 - 下旬平均： $15 \%$ 以下 $=$ 強、15.1 $24.9 \%=$ 中、 $25 \%$ 以上 $=$ 弱 
この結果, ‘やまかおり’の成葉では発病率が やや高かったものの, 病斑は小さく, 抵抗性を やや強と評価した（表16）。

静岡県で実施された自然条件におけるもち病 抵抗性検定試験の結果, 抵抗性が弱の“くらさわ” より発病葉数が少ないものの, ‘やぶきた’よりや や弱いと判断された（表17）。

クワシロカイガラムシの國場での自然発生程 度を調查したところ, ‘ぶきた’より発生はやや 少なく，抵抗性は中と評価された(表18)。しか
しながら,卵数を指標とした検定 ${ }^{3}$ 結果において は, ‘やぶきた’より卵数は少なかったものの, 感 受性と判断される4ことから発生時には防除が必 要である。

\section{6 製茶品質及び化学成分}

煎茶品質は，育成地の栄養系比較試験におい ては,一番茶では‘やぶきた’と同程度であったが, ‘おくみどり’より外観がやや劣った。二番茶では ‘やぶきた, おくみどり'より内質でやや優れた(表

\section{表15 䏍成地における炭疽病発生程度 ${ }^{\mathrm{a}}$}

\begin{tabular}{|c|c|c|c|c|c|c|c|c|c|c|c|c|c|}
\hline \multirow{2}{*}{ 品 種 } & \multicolumn{6}{|c|}{ 栄養系比較試験 } & \multicolumn{5}{|c|}{ 系適試験 } & \multirow{2}{*}{\multicolumn{2}{|c|}{ 全平均 評 価 }} \\
\hline & 89 & 30- & 1991年 & 1992年 & 93年 & 平均 & 1999 f & 2000 & 2001年 & 2002 & 平 $\mathrm{t}$ & & \\
\hline みやまかおり & 3.0 & 2.5 & 2.5 & 2.0 & 4.0 & 2.8 & 1.8 & 1.7 & 2.7 & 2.7 & 2.2 & 2.5 & 中 \\
\hline やぶきた & 4.0 & 3.0 & 4.0 & 2.0 & 4.5 & 3.5 & 3.3 & 3.7 & 3.7 & 3.3 & 3.5 & 5 & 弱 \\
\hline かなやみどり & 3.0 & 2.0 & 2.5 & 2.0 & 3.0 & 2.5 & 2.0 & 1.7 & 2.0 & 2.2 & 2.0 & 2.3 & 中 \\
\hline おくみどり & 4.0 & 2.0 & 3.0 & 3.0 & 4.0 & 3.2 & - & - & - & - & - & 3.2 & 录二や巾弱 \\
\hline さやまかおり & 4.0 & 4.0 & 4.0 & 3.0 & 5.0 & 4.0 & 4.0 & 4.7 & 4.2 & 4.3 & 4.3 & 4.1 & 極弱 \\
\hline
\end{tabular}

a 自然条件下に扔ける発生程度：1 (無) 5 (多)

表16 育成地における輪斑病抵抗性 ${ }^{\mathrm{a}}$

\begin{tabular}{|c|c|c|c|c|c|c|c|c|}
\hline \multirow[b]{2}{*}{ 品 } & \multirow[b]{2}{*}{ 種 } & \multicolumn{2}{|c|}{ 1990年 } & \multicolumn{2}{|c|}{ 1998年 } & \multicolumn{2}{|c|}{ 平均 } & \multirow[b]{2}{*}{ 評 価 } \\
\hline & & $\begin{array}{c}\text { 発病率 } \\
(\%)\end{array}$ & $\begin{array}{c}\text { 病斑径 } \\
(\mathrm{mm})\end{array}$ & $\begin{array}{c}\text { 発病率 } \\
(\%)\end{array}$ & $\begin{array}{c}\text { 病斑径 } \\
(\mathrm{mm})\end{array}$ & $\begin{array}{c}\text { 発病率 } \\
(\%)\end{array}$ & $\begin{array}{c}\text { 病斑径 } \\
(\mathrm{mm})\end{array}$ & \\
\hline & まかおり & 94 & 6.2 & 80 & 8.1 & 87 & 7.2 & やや強 \\
\hline & きた & 95 & 15.4 & 95 & 17.9 & 95 & 16.7 & 弱 \\
\hline & やみどり & 75 & 5.3 & 69 & 6.4 & 72 & 5.9 & やや強 \\
\hline
\end{tabular}

$\mathrm{a}$ 輪斑病分生胞子の付傷接種による検定

$\mathrm{b}$ 評価：1 (強) 5 (弱)

\section{表17もち病抵抗性（静岡県茶業試験場）}

\begin{tabular}{|c|c|c|c|c|c|c|c|c|c|}
\hline \multirow{3}{*}{ 品 } & \multirow{3}{*}{ 種 } & \multicolumn{7}{|c|}{ 発病葉数 ${ }^{\mathrm{a}}$ (枚) } & \multirow{3}{*}{ 評 価 } \\
\hline & & 1995年 & 1996年 & 1997年 & 1998年 & 1999年 & 2000 年 & 2001年 & \\
\hline & & 8 月 & 10月 & 7 月 & 7 月 & 10 月 & 10月 & 7 月 & \\
\hline \multicolumn{2}{|c|}{ みやまかおり } & 0.0 & 1.0 & 3.0 & 57.0 & 10.0 & 0.0 & 0.5 & やや弱〜弱 \\
\hline \multicolumn{2}{|c|}{ やぶきた } & 0.0 & 1.5 & 0.5 & 18.0 & 4.0 & 0.5 & 0.0 & やや弱 \\
\hline \multicolumn{2}{|c|}{ くらさわ } & 0.0 & 3.0 & 15.5 & 92.0 & 17.5 & 6.0 & 3.5 & 弱 \\
\hline \multicolumn{2}{|c|}{ おくひかり } & 0.0 & 1.5 & 0.0 & 8.0 & 1.5 & 0.0 & 0.0 & やや強 \\
\hline
\end{tabular}

a 山間地域における自然発生程度

$1995,1998,1999,2001$ 年は畦長 $1 \mathrm{~m}$ の発病葉数

1996,1997年は全株 (11株) の発病葉数

2000 年は $50 \mathrm{~cm} \times 50 \mathrm{~cm}$ 枠内の発病葉数 
煎茶用品種“みやまかおり’の育成

表18 青成地におけるクワシロカイガラムシの発生程度 ${ }^{\mathrm{a}}$

\begin{tabular}{|c|c|c|c|c|c|}
\hline 品 種 名 & 1998年 & 2000年 & 2001年 & 平 & 評 \\
\hline みやまかおり & - & 2.0 & 2.7 & 2.4 & 中 \\
\hline やぶきた & - & 3.0 & 3.3 & 3.2 & やや弱 \\
\hline かなやみどり & - & - & 3.7 & 3.7 & やや弱 \\
\hline おくみどり & 4.0 & 3.0 & 2.5 & 3.2 & やゃ弱 \\
\hline
\end{tabular}

a 固場における自然発生程度：1(無)〜 5 (多)

表19 育成地の栄養系比較試験における製茶品質 ${ }^{\mathrm{a}}$

\begin{tabular}{|c|c|c|c|c|c|c|c|c|c|c|c|c|c|}
\hline & \multirow{2}{*}{ 種 名 } & \multicolumn{6}{|c|}{ 一番茶 } & \multicolumn{6}{|c|}{ 二番茶 } \\
\hline & & 形状 & 色沢 & 香気 & 水色 & 滋味 & 合計 & 形状 & 色沢 & 香気 & 水色 & 滋味 & 合計 \\
\hline & やまかおり & 8.7 & 7.9 & 7.9 & 7.1 & 7.6 & 39.1 & 8.8 & 8.0 & 7.8 & 8.0 & 7.6 & 40.1 \\
\hline & ぶきた & 8.9 & 7.5 & 7.6 & 7.6 & 7.8 & 39.4 & 8.5 & 7.5 & 6.9 & 7.0 & 6.6 & 36.5 \\
\hline & らやみどり & 8.5 & 6.8 & 7.4 & 8.5 & 7.3 & 38.5 & 8.5 & 8.0 & 6.9 & 7.5 & 7.0 & 37.9 \\
\hline & くみどり & 9.5 & 8.9 & 7.9 & 7.3 & 7.6 & 41.1 & 8.5 & 8.0 & 8.0 & 5.8 & 7.3 & 37.6 \\
\hline
\end{tabular}

a $50 \mathrm{~g}$ 機製茶サンプルの官能審查結果(各項目10点満点)

一番茶は1990 1993年の平均值、二番茶は1991, 1993年の平均值

19)。

系適試験における一番茶の製茶品質は，育成 地では一番茶では‘やぶきた’と同程度, 二番茶で は‘やぶきた’より優れた。また, 各場所について みると,合計点がやぶきだと同程度かそれ以上 を示したところが10場所, やや少ったところが 5 場所, 二番茶においてはそれぞれ8場所及び 3 場所であった。おくみどり’を対照品種として いる佐賀県においては, 一番茶, 二番茶ともおお くみどり’りやや優れた（表20）。なお，年に よっては, 蒸した栗のようなほのかに甘い香気 が感じられた。

荒茶の化学成分は‘やぶきた’に比べ，二番茶で は全窒素及びアミノ酸含有率がやや高く,タン ニン含有率がやや低い傾向がみられたが，一番 茶でははっきりした傾向がみられなかった（表 21)。

\section{4 適地及び栽培上の注意}

耐寒性は赤枯れ抵抗性, 裂傷型凍害抵抗性と も‘やぶきた’と同程度であり, 生育も旺盛で, 寒 冷地の茨城県においてもやや゙きた’以上の生育を しており，暖地，温暖地及び関東地方での栽培 に適していると考えられる。 耐病性では, もち病には弱いので, 常発地帯
では防除が必要である。

新芽長が長く荎がやや太いため, 摘み遅れる と製茶したときに木茎が目立ちやすいので，摘 採時期や摘採方法に留意する必要がある。

\section{5 命名の由来}

‘みやまか抢り’ (深山香) は, 育成地の宮崎県 が日本一の照葉樹林に代表される緑豊かな土地 であることに由来する。

\section{6 摘 要}

‘ややかおり’は, 1983年に宮崎県総合農業試 験場茶業支場において京研 283 ’を種子親, 埼玉 1 号’を花粉親として交配した中から選抜した品 種である。

1994年から2002年まで宮崎20号’系統名で 16場所で系適試験, 2 場所で特性検定試験（も ち病, 裂傷型凍害) が害施された。その結果, “おくみどり’の後に摘採できる品種として普及に 移し得ると判断され，2003年 9 月に茶農林52号 ‘やまかおり’として農林登録された。

みやまかおり'の特性の概要は次のとおりであ る。 
（茶研報96：1 13, 2003)

表20＼cjkstart系適試験における製茶品質 ${ }^{a}$

場所品種名一一番茶一番

\begin{tabular}{|c|c|c|c|c|c|c|c|c|c|c|c|c|c|c|c|}
\hline & & & 形状 & 色沢 & 香気 & 水色 & 滋味 & 合計 & & 形状 & 色沢 & 香気 & 水色 & 滋味 & 合計 \\
\hline & みやまかおり & & 9.3 & 8.9 & 8.8 & 8.9 & $\overline{9.0}$ & 44.8 & & 8.8 & 9.1 & 9.5 & 9.6 & 8.9 & 45.9 \\
\hline 城 & やぶきた & (4) & 7.8 & 8.0 & 8.0 & 8.4 & 8.0 & 40.1 & (4) & 7.4 & 7.5 & 7.1 & 7.3 & 7.4 & 36.6 \\
\hline & かなやみどり & & 7.4 & 7.3 & 7.6 & 7.8 & 7.6 & 37.6 & & 8.3 & 7.5 & 7.5 & 7.1 & 7.5 & 37.9 \\
\hline & みやまかおり & & 8.7 & 8.7 & 9.2 & 8.7 & 8.8 & 44.0 & & 7.7 & 7.8 & 9.0 & 8.0 & 8.8 & 41.3 \\
\hline & やぶきた & (3) & 9.5 & 9.2 & 9.8 & 8.3 & 9.3 & 46.2 & (3) & 7.0 & 9.0 & 9.2 & 9.5 & 9.3 & 44.0 \\
\hline & かなやみどり & & 8.0 & 9.0 & 7.8 & 8.3 & 8.8 & 42.0 & & 9.0 & 9.0 & 8.7 & 9.5 & 9.5 & 45.7 \\
\hline & みやまかおり & & 7.8 & 8.8 & 8.3 & 8.8 & 8.8 & 42.3 & & 8.7 & 8.0 & 8.7 & 8.7 & 8.7 & 42.7 \\
\hline & やぶきた & (4) & 7.0 & 8.3 & 8.5 & 9.0 & 8.3 & 41.0 & (3) & 6.7 . & 6.0 & 7.7 & 7.3 & 8.3 & 36.0 \\
\hline & かなやみどり & & 5.0 & 5.8 & 6.0 & 7.3 & 6.5 & 30.5 & & - & - & - & - & - & - \\
\hline & みやまかおり & & 6.5 & 8.0 & 8.8 & 7.5 & 7.3 & 38.0 & & 7.3 & 7.5 & 9.0 & 7.3 & 8.1 & 39.1 \\
\hline 高 知 & やぶきた & (4) & 9.0 & 9.1 & 9.3 & 8.3 & 7.8 & 43.4 & (4) & 6.6 & 7.1 & 8.3 & 7.8 & 8.6 & 38.4 \\
\hline & かなやみどり & & 7.5 & 8.6 & 6.8 & 9.0 & 8.5 & 40.4 & & 6.5 & 7.8 & 6.0 & 6.5 & 7.8 & 34.5 \\
\hline & みやまかおり & & 10.0 & 9.8 & 9.5 & 9.0 & 9.0 & 47.3 & & 6.0 & 5.0 & 4.0 & 6.0 & 6.0 & 27.0 \\
\hline E本 & やぶきた & (4) & 8.8 & 8.8 & 9.5 & 9.3 & 9.3 & 45.5 & (1) & 7.0 & 6.0 & 5.0 & 6.0 & 6.0 & 30.0 \\
\hline & かなやみどり & & 8.3 & 9.0 & 8.5 & 8.8 & 8.0 & 42.5 & & 7.0 & 6.0 & 6.0 & 6.0 & 5.0 & 30.0 \\
\hline & みやまかおり & & 7.2 & 7.9 & 8.2 & 7.7 & 8.1 & 39.0 & & - & - & - & - & - & - \\
\hline 筝 岡 & やぶきた & (3) & 7.5 & 8.3 & 7.8 & 8.7 & 8.1 & 40.3 & & - & - & - & - & - & - \\
\hline & かなやみどり & & 7.3 & 7.8 & 7.4 & 7.6 & 7.2 & 37.3 & & - & - & - & - & - & - \\
\hline & みやまかおり & (1) & 9.0 & 9.0 & 8.0 & 9.0 & 9.0 & 44.0 & 1 & 9.0 & 9.0 & 10.0 & 9.0 & 8.0 & 45.0 \\
\hline & やぶきた & (1) & 7.0 & 10.0 & 9.0 & 9.0 & 9.0 & 44.0 & (1) & 10.0 & 10.0 & 8.0 & 6.0 & 7.0 & 41.0 \\
\hline & みやまかお & & 9.0 & 7.0 & 10.0 & 8.4 & 7.6 & 42.0 & & - & - & - & - & - & - \\
\hline & やぶ & & 5.0 & 6.0 & 10.0 & 10.0 & 9.6 & 40.6 & & - & - & - & - & - & - \\
\hline & かなやみどり & (1) & 4.0 & 10.0 & 10.0 & 10.0 & 10.0 & 44.0 & & - & - & - & - & - & - \\
\hline & ちくみどり & & 5.0 & 9.0 & 8.8 & 8.8 & 8.8 & 40.4 & & - & - & - & - & - & - \\
\hline & みやまかおり & & 8.2 & 8.5 & 7.2 & 7.8 & 8.2 & 39.8 & & 7.5 & 7.8 & 7.3 & 7.8 & 8.5 & 39.0 \\
\hline 香川 & & (3) & 7.5 & 7.8 & 7.5 & 7.0 & 6.5 & 36.3 & (3) & 9.0 & 9.3 & 8.3 & 8.8 & 8.7 & 44.2 \\
\hline & かなやみどり & & 7.5 & 6.8 & 7.3 & 6.5 & 6.0 & 34.2 & & 7.8 & 7.5 & 7.8 & 6.5 & 7.2 & 36.8 \\
\hline & みやまかおり & & 8.3 & 9.0 & 7.3 & 8.3 & 7.0 & 40.0 & & - & - & - & - & - & - \\
\hline & やぶきた & (3) & 8.7 & 8.0 & 9.3 & 9.0 & 9.3 & 44.3 & & - & - & - & - & - & - \\
\hline & みやま & & 7.2 & 7.5 & 8.8 & 7.3 & 8.8 & 39.7 & & 5.3 & 5.5 & 6.3 & 5.8 & 6.0 & 28.8 \\
\hline 佐 驾 & & (3) & 7.3 & 7.0 & 7.8 & 8.5 & 7.5 & 38.2 & (2) & 4.8 & 4.3 & 6.0 & 5.3 & 6.5 & 26.8 \\
\hline & おくみどり & & 7.2 & 7.3 & 7.5 & 7.3 & 7.7 & 37.0 & & 4.5 & 4.8 & 6.5 & 5.8 & 5.5 & 27.0 \\
\hline & みやまかおり & & 6.0 & 6.0 & 5.8 & 6.0 & 5.5 & 29.3 & & 4.5 & 3.3 & 4.3 & 4.3 & 4.5 & 21.0 \\
\hline 辰 崎 & やぶきた & (3) & 5.5 & 4.7 & 5.3 & 5.7 & 5.3 & 26.5 & & 4.2 & 3.5 & 3.8 & 4.0 & 4.3 & 19.8 \\
\hline & みやまかおり & & 6.0 & 6.5 & 6.0 & 5.7 & 5.3 & 29.5 & & - & - & - & - & - & - \\
\hline 大分 & やぶきた & (2) & 5.5 & 6.5 & 6.0 & 5.3 & 5.7 & 29.0 & & - & - & - & - & - & - \\
\hline & かなやみどり & & 4.5 & 5.5 & 5.7 & 5.7 & 6.3 & 27.7 & & - & - & - & - & - & - \\
\hline & みやまかおり & & 8.2 & 8.0 & 7.9 & 7.1 & 7.7 & 38.9 & & 6.7 & 7.0 & 7.1 & 6.9 & 7.3 & 34.9 \\
\hline 宮 崎 & やぶきた & (4) & 7.6 & 8.2 & 7.4 & 7.4 & 7.6 & 38.2 & (4) & 6.1 & 6.3 & 6.0 & 6.4 & 6.7 & 31.5 \\
\hline & かなやみどり & & 7.4 & 6.9 & 6.9 & 7.4 & 6.4 & 35.1 & & 5.8 & 6.2 & 5.7 & 5.8 & 7.0 & 30.5 \\
\hline & みやまかおり & & 6.8 & 8.2 & 5.7 & 7.3 & 6.2 & 34.1 & & 10.0 & 10.0 & 8.0 & 8.0 & 8.0 & 44.0 \\
\hline 鹿児島 & やぶきた & (3) & 7.8 & 7.8 & 9.2 & 8.7 & 9.2 & 42.6 & (1) & 7.0 & 7.0 & 9.0 & 10.0 & 7.5 & 40.5 \\
\hline & かなやみどり & & 8.5 & 9.1 & 7.3 & 9.2 & 8.0 & 42.1 & & 7.0 & 7.5 & 8.0 & 8.5 & 10.0 & 41.0 \\
\hline
\end{tabular}

a 各項目10点満点（20点満点の場所は10点満点に換算）で，(1)〜(4)はそれぞれ試験年数を示す。 


\begin{tabular}{|c|c|c|c|c|c|c|c|c|c|c|c|c|c|}
\hline \multirow{2}{*}{ 場 所 } & \multirow{2}{*}{ 品種 名 } & \multicolumn{6}{|c|}{ 一番茶 $(\%)$} & \multicolumn{6}{|c|}{ 二番茶 $(\%)$} \\
\hline & & \multicolumn{6}{|c|}{ 全窒素アミノ酸テアニン粗繊維 } & \multicolumn{6}{|c|}{ 全窒素アミノ酸テアニン粗瀻維 カフェインタンニン } \\
\hline \multirow{3}{*}{ 佐 賀 } & みやまかおり & 5.2 & 2.9 & - & - & - & 12.7 & 4.1 & 1.4 & - & - & - & 15.4 \\
\hline & やぶきた & 5.0 & 2.8 & - & - & - & 13.5 & 3.9 & 1.0 & - & - & - & 17.4 \\
\hline & おくみどり & 5.1 & 2.9 & - & - & - & 13.6 & 4.1 & 1.3 & - & - & - & 15.5 \\
\hline \multirow{3}{*}{ 宮 崎 } & みやまかおり & 6.0 & 3.3 & 1.9 & 16.7 & 3.1 & 13.8 & 5.0 & 2.1 & 1.1 & 19.8 & 3.1 & 16.3 \\
\hline & やぶきた & 6.1 & 3.7 & 2.2 & 16.6 & 3.0 & 13.5 & 4.8 & 2.0 & 0.8 & 20.3 & 2.8 & 17.9 \\
\hline & かなやみどり & 5.8 & 3.2 & 1.8 & 17.2 & 3.0 & 14.9 & 4.4 & 1.7 & 0.6 & 21.5 & 2.7 & 17.9 \\
\hline \multirow{3}{*}{ 鹿児島 } & みやまかおり & 5.6 & 3.5 & 1.9 & 19.7 & 2.8 & 12.4 & 4.9 & 2.0 & 1.1 & 21.0 & 3.0 & 15.8 \\
\hline & やぶきた & 5.8 & 3.9 & 2.1 & 18.5 & 2.6 & 12.2 & 4.3 & 1.4 & 0.5 & 23.2 & 2.6 & 17.0 \\
\hline & かなやみどり & 5.7 & 3.5 & 1.9 & 18.6 & 2.8 & 13.4 & 4.3 & 1.2 & 0.6 & 23.5 & 2.6 & 16.1 \\
\hline
\end{tabular}

a 成分は近赤外分光分析計による分析値

佐賀・鹿児島は2000～2002年、宮崎は1999～2002年の平均値

1 ) 一番茶の萌芽期, 摘採期は‘おくみどり’より 2 日程度遅い晚生品種である。

2) 樹姿は中間型, 樹勢は強で, 株張りばやぶ きた’より大さい。摘採期の新葉は淡緑で, やや芽重型である。

3 ）耐病性は, 炭疽病には中, 輪斑病にはやや 強である。

4）而寒性は, 赤枯れ抵抗性がやや強, 裂傷型 凍害抵抗性が中で, ‘やぶきた’と同程度であ る。

5 ）生葉収量は‘やぶきた’より多い。

6 ）煎茶品質は,一番茶では‘やぶきた’と同程度, 二番茶ではややぶだよりやや優れる。また， 蒸した栗のようなほのかに甘い香気が感じ
られる場合がある。

\section{7 引用文献}

1) 古野鶴吉 (1998)：チャ遺伝資源の裂傷型凍 害抵抗性の特性評価. 茶研報, №.86, 37-42.

2 ) 古野鶴吉 (1996)：チャ遺伝資源の輪斑病抵 抗性の特性評価。茶研報, No.83, 41-46.

3 ）水田隆史 (2003)：チャ樹におけるクワシロ カイガラムシの発育と増殖の品種間差異. 応動昆, 47,41-46.

4) 佐藤邦彦・水田隆史 (2003)：チャのクワシ ロカイガラムシ抵抗性品種の利用と物理的 防除の可能性. 今月の農業, $11,43 \sim 46$. 
(茶研報96：1～13，2003）

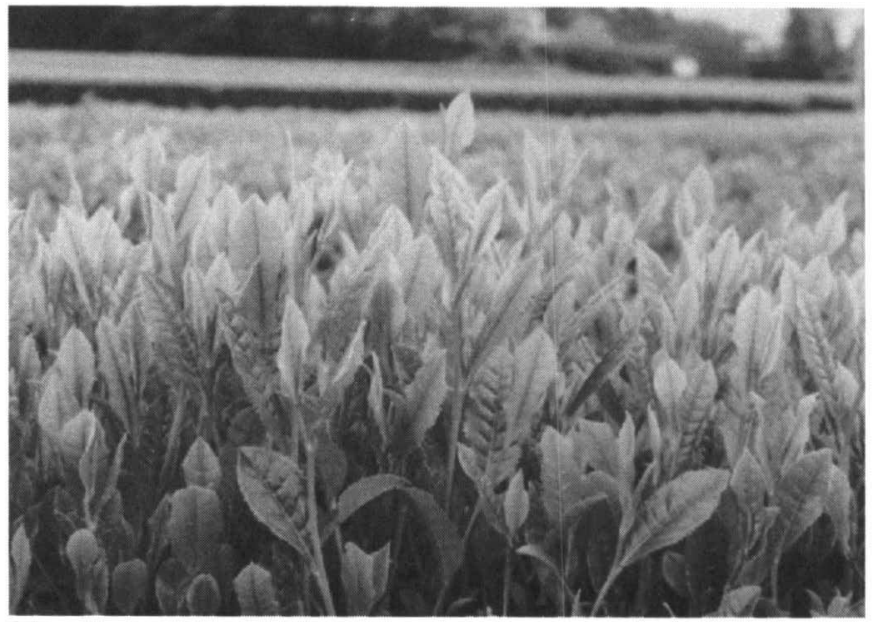

写真 1 ‘みやまかおり’の一番茶摘採期の新芽

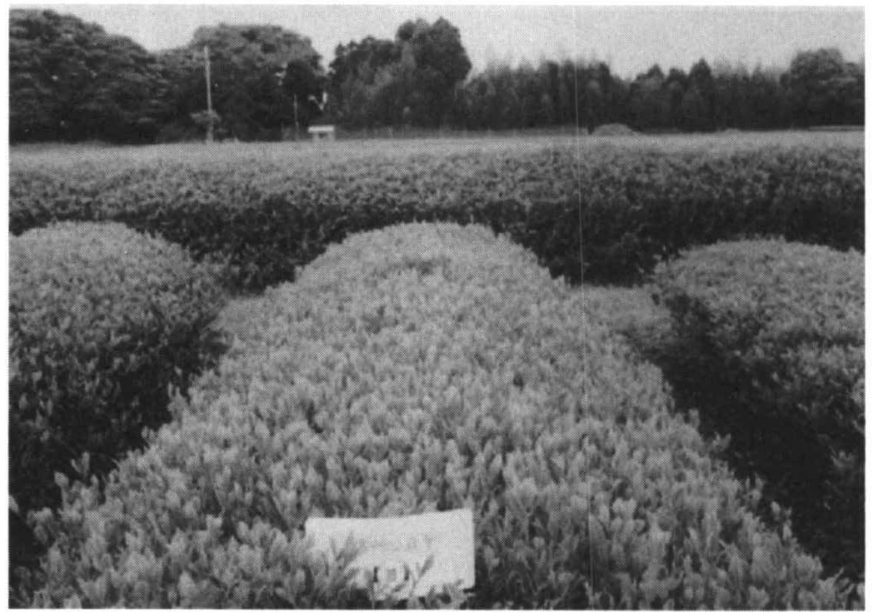

写真 2 ‘やまかおり’の一番茶摘採期の園相 